\title{
Compensation Methods and Employees' Motivation (With Reference to Employees of National Commercial Bank Riyadh)
}

\author{
Alamzeb Aamir \\ College of Business Administration, King Saud University, Riyadh, Saudi Arabia \\ Khawaja Jehanzeb (Corresponding Author) \\ College of Business Administration, King Saud University, Riyadh, Saudi Arabia \\ E-mail: kjehanzeb@ksu.edu.sa \\ Anwar Rasheed \\ College of Business Administration, King Saud University, Riyadh, Saudi Arabia \\ Omair Mujahid Malik \\ College of Business Administration, King Saud University, Riyadh, Saudi Arabia
}

Accepted: August 05, 2012 Published: September 29, 2012

Doi:10.5296/ijhrs.v2i3.2474

URL: http://dx.doi.org/10.5296/ijhrs.v2i3.2474

\begin{abstract}
The main purpose of this research work is to compare the extrinsic and intrinsic rewards which are used as the factors of motivation in the banking sector of Saudi Arabia. With a case study research design, structured interviews were conducted from the eighty (80) employees of NCB seven branched in Riyadh, KSA. The interviews responses were analysed according to Likert technique. After getting scores of ten (10) reward factors, the Pearson correlation technique was calculated to check the relationship between the extrinsic and intrinsic factors and employees motivation. The results show that the employees of NCB were motivated both by the extrinsic and intrinsic rewards, in such way that extrinsic factors were more causing motivation. The analysis result shows that reward management has an intense direct positive relationship with employee motivation level also the intrinsic factors played important role in the motivation process. This research paper stress that banks in public sector shall apply the advance and updated human resource strategy regarding extrinsic and intrinsic rewards.
\end{abstract}

Key Words: Extrinsic Reward, Intrinsic Reward, Employees Satisfaction 


\section{Introduction:}

The world today is facing constant changes especially with regards to technology, innovation and development, and it induces the organizations to review the manner in which they communicate to their employees and customers. There is also a need for these companies to systematise the tasks at hand, re-design systems, organizational processes, and reconsider and improve current management styles (Harmon, 2007). This is mostly important in sectors where there is high competition. An organization to achieve its commitments to shareholders, employees and society, the management should develop a relationship between the organization and employees that will fulfil the continually changing needs of both parties. The organization at minimum expects employees to accomplish reliably the tasks assigned to them and at the standards set for them, and the rules should be followed that have been established to administer the workplace. Management also expect that employees should take initiative, continue to learn new skills, supervise themselves, and be responsive to business needs. The employees at minimum expect their organization to provide fair pay, safe and healthy working conditions, and fair treatment. For organizations to fulfil these expectations the understanding of employee motivation is essential (Beer, Spector, Lawrence, Mills, \& Walton, 1984).

According to the individual-organization exchange theme, individuals join organizations with specific skills, knowledge, experience, desires and goals, and expect in return a work setting where they can use their skills, fulfil their desires, and achieve their goals (Mottaz, 1988). The rewards system of an organization play an important role in maintaining and building the commitment among employees that assure a high standard of performance and workforce retention (Wang, 2004; Young et al., 1998). The rewards included a blend of extrinsic (like performance pay) and intrinsic (like praise) rewards. It was revealed that only negative effect appears when tangible rewards are attached simply for doing a task. This condition carries a small negative impact on intrinsic motivation, as measured by time spent on task following the removal of the reward. These elements become more critical when we talk about financial institutions that have ultimate purpose to provide services and that also of financial basis to entice their customers. So, it's become more important for them to deal in an effective way to their customers.

The strength of any financial service provider lies in its human resources. It is fact that if you have a strength that can be your competitive advantage and is directly linked towards your operations it will help in skirting your threats in external environment. Satisfied and motivated human resources will have convincing influence upon customers and can attract them even in most shocking conditions as we can find nowadays.

\section{Banking Sector in Saudi Arabia}

The banking sector in KSA consists of commercial banks, money transfer and exchange businesses which are working under the authority of Saudi Arabian Monetary Agency (SAMA). According to ministry of interior (March, 2012) up to 2011, 21 banks were operating in the Kingdom (11 domestic banks, 10 foreign banks). The banks offer the full 
range of commercial banking services, and in some cases banks own other companies that offer insurance and securities services (through separate legal entities). Foreign banks are currently prohibited from operating directly within the Kingdom. Banking within Saudi Arabia is regulated by SAMA, in cooperation with other authorities. SAMA also issues and controls currency, regulates money supply and manages foreign assets.

The National Commercial Bank (NCB) was the first Saudi bank to be licensed and the largest and leading financial institution in the Region. The Bank initiated business in the name of "The National Commercial Bank" under Royal Decree on 20 Rabi Thani 1373H (26 December 1953). In year 2011 the Bank was over 280 branches across the Kingdom, where the total number of employees is 5751 specialized in Islamic Banking. NCB has international branches in Beirut and Bahrain and representative offices in London, Seoul and Singapore. The bank owns $64.68 \%$ shares of one of the largest Islamic banks in the world in Turkey. The Bank has a vibrant role in the area of social responsibility through executing various programs, by increasing awareness of sustainability development, regionally and throughout the kingdom (Ministry of Interior, 2012).

\section{Problem Statement}

This research study will analyse the reward (extrinsic and intrinsic) system and to find what motivates employees in baking sector of KSA. The constant growing market demands have literally over loaded employees of banking sector and stretched their working hours in an irrational way. All of this has resulted in employee objections about work-life conflict, work load, stress etc. which really reduced the employee's motivation and affect their performance of banking sector. To keep in view these problems the organizations are using different rewards (extrinsic and intrinsic) policies for motivating their employees. The question is whether banks are applying the suitable rewards (extrinsic and intrinsic) policies according to the needs of employees? Are these strategies accomplishing the anticipated results? Which type of rewards (extrinsic and intrinsic) has more motivational effects? These problems if remained hidden and unaddressed they may rise in other shape of problems like high turnover, demotivation, dissatisfaction of employees and customer etc. and therefore needs to be studied with care.

\section{Objectives of Research}

Following are the main objectives of this study:

1) To determine the level of employees satisfaction in extrinsic rewards.

2) To determine the level of employees satisfaction in intrinsic rewards.

3) To identify the rewards that is positively correlated with employee performance.

\section{Review of Literature}

\subsection{Rewards for employee's motivation}

According to Maslow's needs theory (1956) individual needs starts with basic needs or 
physiological need and are followed by safety needs, social needs, esteem needs and self-actualization needs and according to Swinton (2006) up to esteem needs level employee motivation or satisfaction can be maintained by factors which Herbergz called hygiene factors that include salary, benefits and job security. This includes salary, benefits, job security. The expectancy theory believe that employees will change their behaviour by working harder or prioritizing their actions if they know that by doing so they will be rewarded with something of value to them. Hence, incentives are a great way to reward effort and behaviors which the organization wishes to encourage (Torrington, Hall, Taylor and Atkinson, 2009). While Catanzaro (2001) described the effects of rewards over employee motivation, he stated that reward has a deep effect over employee motivation. In China base salary, merit pay, year-end bonus, cash allowance, housing provision, overtime allowance, and individual bonus were the most important factors to retain and motivate employees (Randy K Chiu et al., 2002). Reward and recognition strategies positively affect motivation, performance and interest of employees within an organization. And a little more problematic, team-based incentives, if designed appropriately, can also boost and support employees for a range of positive outcomes (Patricia Milne, 2007).

Reward is a broad idea that can include anything an employee may value and desire that an employer is able or willing to offer in exchange for employee contribution (Henderson 1989). The productivity of an organization and human resource management has a direct relationship with each other. If employees are managed appropriately i.e. job analysis, recruitment, training, motivational tools like compensation etc. they are destined to give high performance in their operations so will improve the overall productivity of the organization (Ichniowski, 1997; Shaw, 1997; Prennushi, 1997). While Thomas E. Catanzaro (2001) in his article Compensation and Motivation described the effects of rewards over employee motivation. He stated that rewards have a profound effect over employee motivation. He also discussed several factors of compensation which include both intrinsic and extrinsic factors and their possible effects over motivation in detail. He also emphasized that monetary values are not the only motivators but non-monetary factors have more importance towards motivating employees.

Regarding the importance of an effective reward strategy, Brown (2001) says that reward strategy is eventually a way of thinking that one can apply to any reward issue arising in an organization, to see how he/she can create value from it. Hence we can say that the aim of reward strategy is to achieve higher levels of organizational, team and individual performance. Developing and managing a reward system, which is efficient and suited to the organisation, is an essential human resource management function (e.g. Frombrun, Tichy and Devanna 1984; Beer et al. 1985; Hendry and Pettigrew 1990; Schuler and Jackson 1996). From an organisational perspective, the aim of a reward system is to attract, motivate and retain high-quality employees (Lawler 1990; Armstrong 1999; Gomez-Mejia, Balkin and Cardy 2004), as well as to foster high levels of performance (Huselid 1995) but the reward system should be built on an understanding of employees' reward preferences (Lawler 2000). There are several ways to classify means of rewarding, as well as individual reward preferences. In 
this study, rewarding is considered to consist of extrinsic and intrinsic elements (Schuler and Jackson 1996; Armstrong 1999). The origins of this classification can be traced back to the school of human relations. These means of reward should, ideally, create a motivating and effective total reward system. Besides pay, financial rewarding includes bonuses (such as result-based pay), options, stocks, insurance and retirement benefits (Schuler and Jackson 1996; Armstrong 1999).

\subsubsection{Extrinsic Rewards}

According to Mottaz (1988) extrinsic rewards are those that result from extrinsic, non-job-related factors. Social rewards (helpful, friendly and supportive co-workers and considerate supervisors) are those that are derived from interaction with others on the job; while organizational rewards (working conditions, pay satisfaction, benefits, and promotional opportunities) are those that are provided by the organization and are aimed at motivating performance and maintaining membership.

Extrinsic rewards include things like salaries, bonuses commissions, perks, benefits, and cash awards (Flynn, 1999). Wagner's (1985) study showed that extrinsic rewards are not highly correlated with turnover intention. This might be due to the fact that many of the jobs in the service industry have very similar extrinsic rewards and therefore the differences are not enough to cause a person to want to turnover and choose another job that has very similar extrinsic rewards.

\subsubsection{Intrinsic rewards}

Intrinsic rewards more focus on certainty and feeling of fairness in addition to other non-compensatory rewards system. Employees have a sense of achievement when performing a task that is recognized by others to be a contribution to the goals or mission of the organization (Lawler, 1986). The perception of fairness has significant weight in this type of reward (Eisenberger, Rhoades, and Cameron, 1999, Hackman and Stuttle, 1977).

The literature suggests that intrinsic satisfaction is more important in the short term, while extrinsic satisfaction is more important in the long run. This indicates that initially employees find their jobs intrinsically rewarding but over time specific extrinsic rewards lose their motivational power and become "rights" rather than rewards (Urdan and Maehr, 1995).

Intrinsic rewards come to the worker directly from the work they do (Flynn, 1999). People who are motivated intrinsically do not quit very easily. People are at their most creative when they feel motivated primarily by the interest, satisfaction, and challenge of the work itself and not by external pressures or incentives (Marr, 2002). 
Figure 1. A Conceptual frame work on Rewards and Motivation

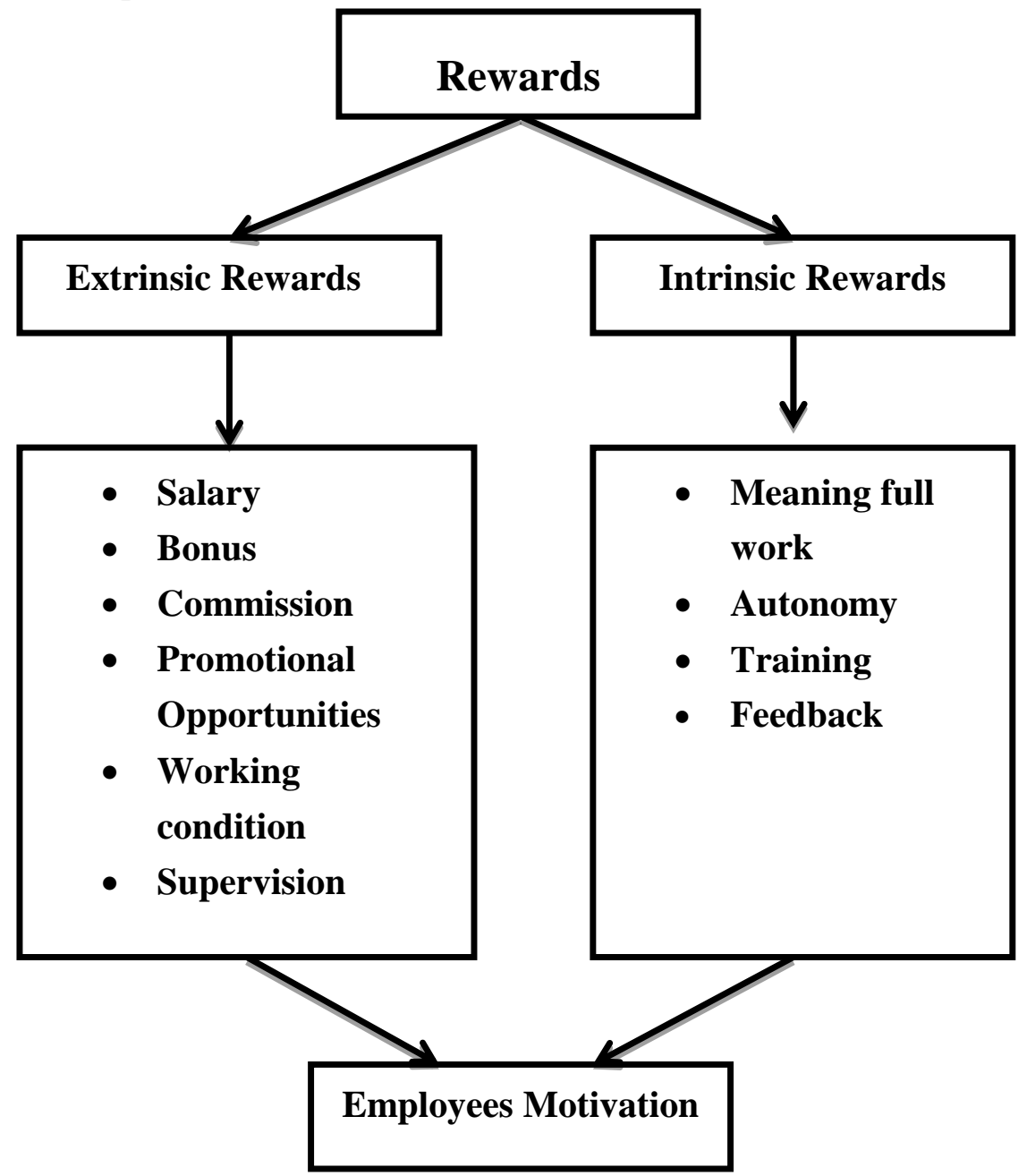

\section{Hypotheses}

For this research work the following hypotheses will be tested

H1. Motivation of employees are directly associated with rewards.

H2. Higher Extrinsic rewards lead to higher employee's motivation.

H3. Higher Intrinsic rewards lead to higher employee's motivation.

\section{Research Methodology}

\subsection{Data Sources}

A case study research design was adopted by taking National Commercial Bank (NCB) of Riyadh, Saudi Arabia special case. Primary and secondary data are used for the present study. Primary data are collected through interviews from 50 employees including managers (branch manager and operation level managers) and non-officer cadre employees like, teller 
and dispatchers, cashiers in National Commercial Bank Riaydh Saudi Arabia. Secondary data are collected from annual reports, journals, books etc.

\subsection{Statistical Tools}

Several statistical techniques like samples, correlation, regression, mean, and percentages analysis were used for this research study. A Pearson's correlation is used when researcher need to find a linear relationship between two variables and can be used in a fundamental as well as an associative research hypothesis. To find the nature of relationship between two variables analysis is performed through regression analysis. The mean analysis is used to specify the comparative size of proration of items rather than entire size whereas the percentage analysis has been used to indicate the relative size of proportion of items rather than absolute size.

\section{Results}

The following table shows the relationship of rewards, extrinsic rewards and intrinsic rewards with employees' motivation in National Commercial Bank (NCB) Riyadh, Saudi Arabia.

Table 1. Relationship of rewards, extrinsic rewards and intrinsic rewards,

\begin{tabular}{|l|c|c|c|}
\hline Indicator & Rewards vs. Motivation & $\begin{array}{c}\text { Extrinsic Rewards vs. } \\
\text { Motivation }\end{array}$ & $\begin{array}{c}\text { Intrinsic Rewards vs. } \\
\text { Motivation }\end{array}$ \\
\hline Regression & $\mathrm{Y}=6.48 \mathrm{x}+0.83$ & $\mathrm{Y}=15.33 \mathrm{x}+1.39$ & $\mathrm{Y}=17.98 \mathrm{x}+1.33$ \\
\hline Correlation & 0.7635 & 0.7280 & 0.5771 \\
\hline R-Square & 0.59 & 0.51 & 0.31 \\
\hline F- Value & 90.45 & 97.17 & 92.31 \\
\hline T- Value & 7.125 & 8.643 & 7.521 \\
\hline
\end{tabular}

\subsection{Rewards vs. Motivation}

The regression analysis shows the positive relationship with rewards and employees motivation. So, if the rewards will be structured according to the needs of employees their motivation will be increased by 6.48. The correlation between rewards and motivation of employees is 0.7635 which shows the positive relationship between rewards and employees. According to regression analysis ( $\mathrm{R}$ - Square) 59\% of employees accepted that they will be motivated with rewards given by the organization. The $\mathrm{F}-$ Value i.e. 90.45 shows the 
relationship between the variables. Similarly the $\mathrm{T}-$ Test calculated value i.e. 7.125 , which is greater than the critical value 1.6663 shows the positive relationship between rewards and motivation of employees in NCB Saudi Arabia.

\subsection{Extrinsic Rewards vs. Motivation}

In comparative study of extrinsic rewards and employees motivation the regression equation shows the progressive relationship between extrinsic rewards and motivation. Therefore, the employee's motivation will be improved by 15.33 if the extrinsic rewards will be given according to the needs of employees. Similarly the correlation between extrinsic rewards and motivation result i.e. 0.7280 shows the positive relationship between the two variables. The Regression analysis ( $\mathrm{R}$ - Square) 0.51 or $51 \%$ of total employees are in favour of motivation through extrinsic rewards. The F - Value is greater than the table value, which shows the relationship between the extrinsic rewards and employees motivation. The $\mathrm{T}-$ test value is 8.643 which is greater than the critical value 1.6663 , proved the positive relationship between the variables (at5\% of significance level).

\subsection{Intrinsic Rewards vs. Motivation}

The regression equation shows the positive relationship between intrinsic rewards and employees motivation. The employee's motivation will be increased by 17.98 if the bank made the required intrinsic rewards according the needs of employees. The correlation result i.e. 0.5771 shows a positive relationship between the variables. The $\mathrm{R}-$ Square and $\mathrm{t}-$ Value also show positive relationship between the two variables.

\section{Findings and Implications}

The first hypothesis H1: Rewards plans are significantly associated with extrinsic and intrinsic factors of motivation are accepted. Because, the result shows that about $80 \%$ of the employees in National Commercial bank (NCB) are directly motivated with rewards offered. Therefore, we conclude that there is positive relationship with rewards and employees motivation. However, the following elements should also be added in the current reward system i.e. loan facility should be given to employees with minimum interest, medical facility should be given to employees and their family, employees should be given favourable leave facility due to job stress and anxiety. The second hypothesis H2: Higher Extrinsic rewards lead to higher employee's motivation is also accepted. The employees of NCB employees favour the extrinsic rewards like Salary, Bonus, Commission, Promotional Opportunities, Working condition, Supervision. The bank should emphasise more on extrinsic rewards in motivating employees. The third hypothesis H3: Higher Intrinsic rewards lead to higher employee's motivation could not be rejected as well, because more than half of respondents also preferred the intrinsic rewards. So, the management should not only consider the extrinsic rewards for the motivation of employees but also should give importance to employees training, autonomy and feedback.

\section{References}




\section{Macrothink}

- Armstrong, M., \& Murlis, H. (1991). Reward management. London: Kogan Page Ltd.

- Armstrong, M. 1993 Managing Reward Systems. Buckingham: Open University Press.

- Beer, M., Spector, B., Lawrence, P. R., Mills, D.Q., Walton, R. E. (1984). A Conceptual View of HRM. In Managing Human Assets. Free Press, New York Chap.2.

- Brown, D. (2001), Reward Strategies; form intent to impact, London: CIPD.

- Catanzaro, TE (2001). 'Compensation \& Motivation'. Journal of Veterinary Emergency and Critical Care, 11, 62-65.

- Casey Ichniowski, Kathryn Shaw and Giovanna Prennushi (1997). "The Effects of Human Resource Management Practices on Productivity: A Study of Steel Finishing Lines" The American Economic Review (C) American Economic Association.

- Ensher, E.A., Thomas, C., and Murphy, S.E. (2001). 'Comparison of Traditional, Step-Ahead, and Peer Mentoring on Proteges' Support, Satisfaction, and Perceptions of Career Success: A Social Exchange Perspective,' Journal of Business and Psychology, 15, 419-438.

- $\quad$ Eisenberger, R. Rhoades, L., \& Cameron, J. (1999). Does pay for performance increase or decrease perceived self-determination and intrinsic motivation? Journal of Personality \& Social Psychology, 5, 1226 - 1240.

- Flynn, J. (1999). Motivating an increasingly diverse workforce. Campus Dining Today, 16-21.

- Frombrun, C., Tichy, N.M., and Devanna, M.A. (eds.) (1984). Strategic Human Resource Management, New York: Wiley.

- Gomez-Mejia, L.R., Balkin, D.B., and Cardy, R.L. (2004). Managing Human Resources (4th ed.), Upper Saddle River, NJ: Prentice Hall.

- Glisson, C. and Durick ,M. (1988). 'Predictors of Job Satisfaction and Organizational Commitment in Human Service Organizations', Administrative Science Quarterly, 33(1): 61-81

- Hackman, J. \& Stuttle, J. (Eds.) (1977). Improving life at work. Santa Monica, CA: Goodyear.

- Hackman, J.R. and Oldham, G.R. (1976). 'Motivation through the Design of Work: Test of a Theory', Organizational Behavior and Human Performance, 16: 250-79.

- Henderson, R. I., Compensation Management: Rewarding Performance, Reston, Virginia, Reston Publication (1989).

- Hendry, C., and Pettigrew, A.M. (1990), 'Human Resource Management: an Agenda for the 1990's,' International Journal of Human Resource Management, 1, 1, 17-43.

- Huselid, M.A. (1995). 'The Impact of Human Resource Management Practices on Turnover, Productivity and Corporate Financial Performance,' Academy of Management Journal, 38, 3, 635-672.

- Ichniowski, Casey, Thomas A. Kochan, David Levine, Craig Olson, and George Strauss (1997). "What Works at Work: Overview and Assessment," Industrial Relations, vol. 35 (July), pp. 299-333.

- Kreitner R. and A.Kinick (1992). Organization Behavior, Second ed., Richard D. Irwin, Inc, USA 
- Lawler, E.E. III. (1990). Strategic Pay. Aligning Organizational Strategies and Pay Systems, San Francisco, CA: Jossey-Bass Inc.

- Lawler, E.E. (2000). Rewarding Excellence: Pay Strategies for the New Economy, San Francisco, CA: Jossey-Bass Inc.

- Marr,J. (2002).Commentary: flow, intrinsic motivation, and $2^{\text {nd }}$ generation cognitive science. Retrieved from: ttp://www.athleticinsight.com/vo12iss3/commentary_2.htm.

- Mottaz, C.J. 1988 'Determinants of Organizational Commitment', Human Relations, 41(6): 467-482.

- Ministry of Interior (MoI), Financial Investigation Unit, Saudi Arabia. http://www.moi.gov.sa.

- Patricia Milne (2007). "Motivation, Incentives and Organizational Culture", Journal of Knowledge Management; Volume: 11 Issue: 6.

- Randy K. Chiu and Richard D. Babcock (2002). "The relative importance of facial attractiveness and Gender i Hong Kong Selection Decision", International Journal of human resource management. 13:1, Pp: $141-155$.

- Schuler, R.S., and Jackson, S.E. (1996). Human Resource Management: Positioning for the $21^{\text {st }}$ Century (6th ed.), New York: West Publishing Company.

- Swinton, L (2006). How To Increase Your Work and Life Satisfaction: Put Abraham Maslow Theory Into Practice. Viewed 20 March 2012. http://www.mftrou.com/abraham-maslow-theory.html.

- Torrington, Derek. Hall, Laura. Taylor, Stephen \& Atkinson Carol. (2009). Fundamentals of Human Resource Management, 1st edition. Pearson Education Limited, 439

- Urdan, T., \& Maehr, M. (1995). Beyond a two-goal theory of motivation and achievement: A case for social goals. Review of Educational Research, 65(3), 213-243.

- Wang, Y. (2004) 'Observations on the Organizational Commitment of Chinese Employees: Comparative Studies of State-Owned Enterprises and Foreign-Invested Enterprises', The International Journal of Human Resource Management, 15(4/5): 649-64.

- Wagner, E. M. (1985). Air Force First-term Turnover: An Institutional Value Model (Intrinsic-extrinsic).Dissertations, University of Illinois at Urbana-Champaign. 